\title{
The effect of pistachios on human health: A review study
}

\author{
Shahrabadi E, $\mathrm{MSc}^{1 *}$, Esmaeili Nadimi A, MD ${ }^{2}$, Jalali N, BSc${ }^{3}$, Shahrabadi AR, BSc ${ }^{4}$, \\ Shahreiyari A, BSc ${ }^{5}$, Asadollahi N, $\mathrm{MSc}^{6}$ \\ 1- MSc in Medical Education, Rafsanjan University of Medical Sciences, Rafsanjan, Iran. 2-Associate Prof., Cardiologist, Dept. \\ of Internal Medicine, Rafsanjan University of Medical Sciences, Rafsanjan, Iran. 3-BSc in Information Technology, Vali-e-Asr \\ University of Rafsanjan, Rafsanjan, Iran. 4- BSc in Hadith Sciences, Organization of Education of Rafsanjan, Rafsanjan, Iran. \\ 5- BSc in Nursing, Rafsanjan University of Medical Sciences, Rafsanjan, Iran. 6- MSc Student, Rafsanjan Branch, Islamic Azad \\ University, Rafsanjan, Iran.
}

\begin{abstract}
Received: January 2016, Accepted: July 2016

Background: Health is an important pillar of human life and the pistachio is among the nuts which have an impact on human health. The aim of this study was to review the effects of pistachios on human health. Materials and Methods: This was a review study. Data were collected from PubMed and from among articles published from the year 2005 to 15 July 2015 using the keyword pistachio in combination with cholesterol, cardiovascular, health, consumption, diabetes, serum lipid levels, glucose, and metabolic syndrome.

Results: Of the total of 194 articles searched, 19 articles were included in the study. The consumption of pistachio, due to its minerals, vitamins, proteins, and antioxidants, improved health and had a positive impact on health outcomes, such as fat, blood sugar, and weight control. It also helped in the promotion of a healthy heart and recovery of high blood pressure, diabetes, coronary heart disease (CHD), metabolic syndrome, and pre-diabetes.

Conclusions: Pistachio, due to its nutrients, has positive impact on human body health, including the cardiovascular system, blood lipids, and blood pressure. Moreover, because of its unsaturated fats, it also affects the lipoproteins and reduces cardiovascular disease (CVD) and diabetes, and helps in the management of weight and metabolic syndrome. It can also help in the recovery of patients with prediabetes through changes in their harmful metabolism. Pistachios are recommended as part of a healthy diet for the human health and prevention of chronic non-infectious diseases.
\end{abstract}

Keywords: Pistachio, Health, Cardiovascular System, Blood Sugar, Diabetes Mellitus, Prediabetes, Body Weight, Metabolic Syndrome

\section{Introduction}

Today, a combination of population growth, population aging, increase in cardiovascular diseases (CVDs), chronic diseases and disabling conditions, reduced quality of life (QOL), mortality, and increased financial burden has become a social concern (1). Primary prevention of these phenomena with a healthy diet containing nuts, such as walnuts (1), almonds (2), and pistachios (3), is possible.

Research has shown that almonds have high unsaturated fats and affect the blood lipids (decrease triglycerides, total cholesterol, and LDL), and guarantees the health of women and men (4). On the other hand, consumption of 43 grams of walnuts for 8 weeks significantly reduced non-HDL-cholesterol and apolipoprotein-B which has resulted in the reduction of the rate of heart disease (5).

Among nuts (almonds, hazelnut, peanuts, pecans, and walnuts), pistachios contain lower

\footnotetext{
Corresponding author: Effat Shahrabadi, Rafsanjan University of Medical Sciences, Rafsanjan, Iran Email: s_e_1400@yahoo.com
} 
fat, and energy content, the highest levels of vitamin $\mathrm{K}$, vitamin B6, B1, protein, and fiber, and high levels of antioxidants, including anthocyanins, flavonoids, proanthocyanidins flavonols, is flavones, flavanones, and stilbenes (3). Research has shown that pistachios contain $50 \%-70 \%$ fat the majority of which is unsaturated fatty acids that prevent cholesterol accumulation and atherosclerosis (6) and reduce the incidence of heart disease including coronary artery disease (CAD) (7). Darhar, in an article, stated that pistachio is a nutritious nut with a heart-healthy fatty acid profile (8). Therefore, it is considered very important in the diet because it plays an important role in the maintenance of cells and blood pressure control (9). Minerals $(\mathrm{Cu}, \mathrm{Mg}, \mathrm{Mn}, \mathrm{K}$, and $\mathrm{Ca})$ and vitamins $(\mathrm{A}, \mathrm{B}$, and $\mathrm{C}$ ) in pistachio are suitable for the health of many parts of the body such as the heart, blood vessels, immune system, and eyes (10). In addition, Kendall et al. noted that consumption of pistachios alone had little effect on postprandial blood sugar, but when consumed with carbohydrates it caused a reduction in relative glycemic response (RGR) (11). In other words, nuts due to their desirable fat and protein can lower postprandial blood sugar, and thus, reduce the risk of heart disease and diabetes (11). In another study, the role of pistachios in glucose level was compared to that of the Mediterranean diet (vegetables, fish and red meat, fat, and eggs) (12). It was found to improve the blood glucose level and endothelial dysfunction and oxidative stress (12).

In the human body, oxygen reactions naturally occur in different ways, such as superoxide, hydrogen peroxide, and hydroxyl radicals, and in increased amounts, they damage the tissues (oxidative stress). Therefore, antioxidants found in foods, including pistachios, minimize them, and thus, prevent arteriosclerosis and cancers (13). Today, the most common dimension of health is physical health which results from the normal function of organs such as normal pulse, blood pressure, suitable weight gain in the growth ages, stable weight later in life, sufficient appetite, and regular bowel movements (14). In addition, a healthy diet including nuts is one of the key factors of success in life and improper nutrition endangers the body and mind, affects health, and causes mortality and attrition diseases such as hypertension, diabetes, and atherosclerosis (15). Although the pistachio is widely planted in Iran, few studies have been conducted on the effect of its nutrients on health within the country. Therefore, this study aimed to review the effects of pistachios on human health (including cardiovascular system, blood sugar and fat, blood pressure, body weight, CVD, diabetes, and metabolic syndrome).

\section{Materials and Methods}

This was an analytical review study. Data were collected from PubMed and from among articles published from 2005 to 15 of July 2015. First, the word pistachio was searched on PubMed and the keywords mentioned by the proposed site were reviewed, and then, the following words were extracted and the search was conducted.

Pistachio consumption

Pistachio cholesterol

Pistachios and diabetes

Pistachio consumption and serum lipid levels

Pistachio diabetes

Pistachio cardiovascular

The following keywords were searched.

Pistachio AND consumption

Pistachio AND diabetes

Pistachio AND cholesterol

Pistachio AND cardiovascular

Pistachio AND serum lipid

Pistachio AND glucose

Pistachio AND metabolic syndrome

Pistachio AND health

The inclusion and exclusion criteria of the study included all articles on the objectives of the study (pistachio and health) which were conducted during 2005 to $15 / \mathrm{July} / 2015$ and 
written in English in the scientific website of PubMed. Articles which were conducted on the effect of pistachio consumption on animals were excluded from the study. Literature review was performed independently by two researchers and all searched articles were evaluated after the resolution of disputes with respect to the relevancy of the subject.

\section{Results}

Of the total of 194 articles searched, considering the purposes of the study, subject relevancy, and lack of repetition of articles, 19 articles were included in the study. The findings are divided into two categories and presented in this article. The effects of pistachios on the cardiovascular system, CVDs, and fats: Pistachio consumption has beneficial effects on health outcomes, such as high blood pressure, diabetes, coronary heart disease (CHD), and mortality (3). Due to its variety of antioxidants, the pistachio prevents CVD. These compounds, as protection against free radicals, are effective in CVD (3).

Kazlival et al. studied 60 randomly selected subjects with mild dyslipidemia (16). They investigated lifestyle changes alone or lifestyle modification with the consumption of 80 grams of pistachios with shells, equivalent to 40 grams or 1.5 ounces, for 3 months. They reported that changes in biochemical and clinical parameters were not observed in individuals who had a lifestyle modification alone. However, in the group that consumed pistachios, there was a significant increase in the amount of highdensity lipoprotein cholesterol (HDL) and a decrease in low-density lipoprotein cholesterol (LDL), and overall, the total cholesterol to HDL levels and fasting blood glucose were significant. They also reported that regular consumption of pistachio not only improved lipid and blood sugar, but also improved the hardening of the arteries and endothelial function (16). A study was conducted in 2007 by Sheridan et al. on individuals with average high blood fat (serum cholesterol greater than 210 $\mathrm{mg} / \mathrm{dl})$ (17). These individuals had a pistachio diet consisting of $15 \%$ calories (about 2 to 3 ounces per day) for 4 weeks and showed good improvement in blood lipid levels. They stated that this improvement could reduce the risk of CHD (17). Pistachio consumption reduced oxidative stress and improved cholesterol levels and HDL in healthy individuals (18). Saril et al. conducted a study on 33 healthy young men (19). Their subjects had the Mediterranean diet for 4 weeks, and then, added pistachios to the diet (by replacing 32\% of the energy obtained by polyunsaturated fatty acids in the Mediterranean diet). They stated that pistachios, compared with the Mediterranean diet, improved blood glucose levels, endothelial function, some inflammatory markers, and oxidative status (19). A diet including pistachios helps the health of the heart through reducing serum LDL by reducing cholesterol (20).

Including pistachios in a healthy diet (depending on dose) and consumption of tree nuts (including pistachios, almonds, hazelnuts, and walnuts) affect cardiovascular risk factors $(21,22)$. Other sources stated that ideally the consumption of pistachio is effective on heart metabolism in patients with increased risk of $\operatorname{CAD}(17,21,23)$. Researchers in a study stated that a moderate-fat pistachio diet, on average, improves some cardiovascular risk factors in adults with controlled type II diabetes (Table 1) (24).

Table 1: Literature review of studies on the effect of pistachio on health

\begin{tabular}{|c|c|c|c|c|}
\hline $\begin{array}{c}\text { Researcher and } \\
\text { year }\end{array}$ & Study aim & $\begin{array}{c}\text { Study type and sample } \\
\text { size }\end{array}$ & Amount consumed & Conclusion \\
\hline $\begin{array}{c}\text { Bulló et al. (3), } \\
2015\end{array}$ & $\begin{array}{c}\text { A review of the health } \\
\text { effects of nutrients and } \\
\text { phytochemicals of pistachio }\end{array}$ & $\begin{array}{c}\text { epidemiological and } \\
\text { clinical evidence- (review } \\
\text { study) }\end{array}$ & - & $\begin{array}{c}\text { Increased health due to antioxidants } \\
\text { and anti-inflammatory properties }\end{array}$ \\
\hline
\end{tabular}




\begin{tabular}{|c|c|c|c|c|}
\hline $\begin{array}{l}\text { Driver et al. (8), } \\
2012\end{array}$ & $\begin{array}{l}\text { A review of the } \\
\text { phytochemicals and } \\
\text { nutrients in pistachios and } \\
\text { the health effects of nuts }\end{array}$ & Review study & - & $\begin{array}{l}\text { Beneficial effects on blood lipids, } \\
\text { decreased oxidative and inflammatory } \\
\text { stress, and improved blood vessel } \\
\text { health, blood sugar control, appetite } \\
\text { management, and weight control }\end{array}$ \\
\hline $\begin{array}{l}\text { Kendall et al. (11), } \\
\qquad 2014\end{array}$ & $\begin{array}{l}\text { Effect of pistachios on } \\
\text { postprandial glucose, } \\
\text { insulin levels, and gut } \\
\text { hormones }\end{array}$ & $\begin{array}{l}\text { RCT, } 20 \text { subjects with } \\
\text { metabolic syndrome }\end{array}$ & $\begin{array}{c}5 \text { study meals: } \\
3 \text { meals had } 50 \mathrm{~g} \\
\text { available } \mathrm{CHO}:(\mathrm{WB} 50 \\
\text { g), (WB+B+Ch), } \\
(\mathrm{WB}+\mathrm{P}) \\
2 \text { meals had } 12 \mathrm{~g} \\
\text { available } \mathrm{CHO}: \\
\text { (WB } 12 \mathrm{~g}),(\mathrm{P}) .\end{array}$ & $\begin{array}{c}\text { Low postprandial blood sugar, } \\
\text { increased levels of glucagon-like } \\
\text { peptide }\end{array}$ \\
\hline $\begin{array}{l}\text { Kasliwal et al. (16), } \\
\qquad 2015\end{array}$ & $\begin{array}{l}\text { Health effects of pistachios } \\
\text { on blood vessels }\end{array}$ & $\begin{array}{l}\text { RCT, } 60 \text { adults with mild } \\
\text { dyslipidemia }\end{array}$ & $\begin{array}{c}80 \mathrm{~g} \text { pistachios (with } \\
\text { shell) (equivalent to } 40 \mathrm{~g} \\
\text { or } 1.5 \mathrm{oz} \text {. shelled } \\
\text { pistachios)/ daily for } 3 \\
\text { months }\end{array}$ & $\begin{array}{l}\text { Beneficial effects on glucose and } \\
\text { lipids, and improved atherosclerosis } \\
\text { and endothelial function }\end{array}$ \\
\hline $\begin{array}{l}\text { Sheridan et al. (17), } \\
\qquad 2007\end{array}$ & $\begin{array}{l}\text { Effects of consuming } 15 \% \\
\text { of the daily caloric intake in } \\
\text { the form of pistachio nuts } \\
\text { on the lipid profiles }\end{array}$ & $\begin{array}{l}\text { RCT, } 15 \text { subjects with } \\
\text { primary, moderate } \\
\text { hypercholesterolemia }\end{array}$ & $\begin{array}{l}\text { Intervention: } 15 \% \text { caloric } \\
\text { intake from pistachio nuts } \\
\text { for } 4 \text { weeks }\end{array}$ & $\begin{array}{l}\text { Improved level of blood lipids and } \\
\text { reduced cardiovascular disease }\end{array}$ \\
\hline $\begin{array}{l}\text { Kocyigit et al. (18), } \\
2006\end{array}$ & $\begin{array}{l}\text { The effect of pistachios on } \\
\text { healthy volunteers } \\
\text { regarding plasma lipids and } \\
\text { oxidative status }\end{array}$ & $\begin{array}{l}\text { RCT, } 24 \text { healthy men and } \\
20 \text { healthy women with } \\
\text { normal lipid levels }\end{array}$ & $\begin{array}{l}\text { Replacing } 20 \% \text { of their } \\
\text { daily caloric intake with } \\
\text { pistachio nuts for } 3 \text { weeks }\end{array}$ & $\begin{array}{l}\text { Reduced oxidative stress, and } \\
\text { improved cholesterol and HDL }\end{array}$ \\
\hline $\begin{array}{l}\text { Sari Ibrahim et al. } \\
\quad(19), 2010\end{array}$ & $\begin{array}{l}\text { Effect of Antep pistachio } \\
\text { (Pistacia vera L.) on blood } \\
\text { glucose, lipid parameters, } \\
\text { endothelial function, } \\
\text { inflammation, and } \\
\text { oxidation in healthy young } \\
\text { men } \\
\end{array}$ & $\begin{array}{l}32 \text { healthy young men } \\
\text { For } 4 \text { week }\end{array}$ & $\begin{array}{l}\text { Mediterranean diet for } 4 \\
\text { weeks } \\
\text { Replacing } 20 \% \text { of daily } \\
\text { caloric intake with } \\
\text { pistachio in the } \\
\text { Mediterranean diet for } 4 \\
\text { weeks } \\
\end{array}$ & $\begin{array}{c}\text { Improvement in blood glucose levels, } \\
\text { endothelial function, and oxidative } \\
\text { status }\end{array}$ \\
\hline key et al. (20), 2010 & $\begin{array}{l}\text { Evaluation of the effect of } \\
\text { pistachios on serum } \\
\text { antioxidants and } \\
\text { biomarkers of oxidative } \\
\text { status }\end{array}$ & $\begin{array}{l}\text { RCCT, } 28 \text { adults with } \\
\text { hypercholesterolemia }\end{array}$ & $\begin{array}{c}\text { Control diet: lower-fat } \\
\text { without pistachios }(25 \% \\
\text { total fat) } \\
\text { pistachio diet: }(1 \mathrm{PD}) \\
10 \% \text { energy, } 32-62 \mathrm{~g} / \mathrm{d}) \\
\text { pistachio diet: }(2 \mathrm{PD}) \\
20 \% \text { energy, } 63-122 \mathrm{~g} / \mathrm{d} \\
\text { For } 4 \text { weeks }\end{array}$ & $\begin{array}{l}\text { Improved heart health by reducing } \\
\text { oxidative serum and LDL through } \\
\text { decreasing cholesterol and } \\
\text { antioxidant effects }\end{array}$ \\
\hline $\begin{array}{l}\text { Gebauer et al. (21), } \\
2008\end{array}$ & $\begin{array}{l}\text { Impact of } 2 \text { doses of } \\
\text { pistachio on the low-fat diet } \\
\text { lipids and lipoproteins, } \\
\text { apolipoprotein (apo) - } \\
\text { defined lipoprotein } \\
\text { subclasses, and plasma fatty } \\
\text { acids }\end{array}$ & $\begin{array}{l}\text { RCCT, } 28 \text { individuals with } \\
\text { hyperlipidemia }\end{array}$ & $\begin{array}{c}\text { Control diet: lower-fat } \\
\text { with no pistachios ( } 25 \% \\
\text { total fat) } \\
\text { pistachio diet: (1 PD) } \\
10 \% \text { energy } \\
\text { pistachio diet: ( } 2 \mathrm{PD}) \\
20 \% \text { energy } \\
\text { For } 4 \text { weeks } \\
\end{array}$ & Reduced risk factors and CVD \\
\hline $\begin{array}{l}\text { O'Neil et al. (22), } \\
\qquad 2015\end{array}$ & $\begin{array}{l}\text { The impact of tree nut } \\
\text { consumption on risk factors } \\
\text { for metabolic syndrome and } \\
\text { CVD }\end{array}$ & $\begin{array}{l}14386 \text { participants with } \\
\text { CVRF or MetS }\end{array}$ & $\begin{array}{l}\text { Non-consumers of tree } \\
\text { nuts }<1 / 4 \text { ounce/day } \\
\text { consumers of tree nuts } \\
\geq 1 / 4 \text { ounce/day } \\
\text { using data from } 24 \text {-hour } \\
\text { dietary recalls } \\
\end{array}$ & $\begin{array}{l}\text { Improvement in weight, some } \\
\text { components of cardiovascular risk } \\
\text { factors, and metabolic syndrome }\end{array}$ \\
\hline $\begin{array}{l}\text { Holligan et al. (23), } \\
\qquad 2014\end{array}$ & $\begin{array}{l}\text { The effect of cholesterol- } \\
\text { lowering diet including } \\
\text { pistachios on increasing the } \\
\text { level of full fat in } \\
\text { comparison to low-fat diet }\end{array}$ & $\begin{array}{l}\text { RCCF, } 28 \text { individuals with } \\
\text { LDL } \geq 2.86 \mathrm{mmol} / 1\end{array}$ & $\begin{array}{l}\text { Control diet: } 25 \% \mathrm{TF} \\
\text { Diet 1: one serving of } \\
\text { pistachios per d (1 PD; } \\
30 \% \mathrm{TF}) \\
\text { Diet 2: two servings of } \\
\text { pistachios per d (2 PD; } \\
34 \% \mathrm{TF})\end{array}$ & $\begin{array}{l}\text { Pistachios with a moderate-fat diet } \\
\text { had positive effect on cardio- } \\
\text { metabolic profile in individuals with } \\
\text { increased risk of CVD (Reduction in } \\
\text { sdLDL, TAG, HDL, increased levels } \\
\text { of alpha-performance one and two } \\
\text { HDL particles). }\end{array}$ \\
\hline
\end{tabular}




\begin{tabular}{|c|c|c|c|c|}
\hline $\begin{array}{c}\text { Sauder et al. (24), } \\
2014\end{array}$ & $\begin{array}{c}\text { Effect of pistachio } \\
\text { consumption on BP, } \\
\text { systemic hemodynamics, } \\
\text { and heart rate }\end{array}$ & $\begin{array}{c}\text { RCCT, } 30 \text { adults with type } \\
2 \text { diabetes }\end{array}$ & $\begin{array}{c}\text { control diet: low-fat, } 27 \% \\
\text { fat } \\
\text { 2-week washout } \\
\text { moderate-fat diet: } 33 \% \\
\text { fat, containing pistachios } \\
\text { with } 20 \% \text { of total energy } \\
\text { for } 4 \text { weeks each } \\
\end{array}$ & $\begin{array}{l}\text { In case of type II diabetes control in } \\
\text { adults, improvement of CVD risk } \\
\text { factors with a moderate fat diet }\end{array}$ \\
\hline $\begin{array}{l}\text { Hernández-Alonso } \\
\text { et al. }(25), 2015\end{array}$ & $\begin{array}{l}\text { Reviewing the changes in } \\
\text { lipoprotein derivatives in } \\
\text { individuals with pre- } \\
\text { diabetes compared to } \\
\text { healthier individuals }\end{array}$ & $\begin{array}{l}\text { RCCT, } 54 \text { subjects with } \\
\text { pre-diabetes }\end{array}$ & $\begin{array}{l}\text { Group I: pistachio- } \\
\text { supplemented diet } \\
\text { including } 57 \mathrm{~g} / \text { day } \\
\text { Group II: control diet } \\
\text { For } 4 \text { months each }\end{array}$ & $\begin{array}{l}\text { Change in the size of lipoprotein } \\
\text { particles and derivatives, changes in } \\
\text { the lipid profile, reduction in the risk } \\
\text { of CVD and mortality }\end{array}$ \\
\hline $\begin{array}{l}\text { Hernández-Alonso } \\
\text { et al. (26), } 2014\end{array}$ & $\begin{array}{l}\text { Investigation of the effect } \\
\text { of a diet rich in pistachios } \\
\text { on reducing pre-diabetes } \\
\text { and metabolic risk profile }\end{array}$ & RCT, 54 subjects & $\begin{array}{l}\text { Group I: pistachio- } \\
\text { supplemented diet (PD) } \\
\text { Group II: control diet } \\
\text { (CD) } \\
\text { For } 4 \text { months }\end{array}$ & $\begin{array}{l}\text { Improvement in pre-diabetes (reduced } \\
\text { blood glucose and fasting insulin, and } \\
\text { promoted healthier metabolic profile) }\end{array}$ \\
\hline $\begin{array}{l}\text { Heidari et al. (27), } \\
2014\end{array}$ & $\begin{array}{l}\text { Effectiveness of pistachio } \\
\text { nut supplementation on } \\
\text { glycemic and inflammatory } \\
\text { measures }\end{array}$ & $\begin{array}{l}\text { RCCT, } 48 \text { patients with } \\
\text { type II diabetes }\end{array}$ & $\begin{array}{l}\text { Group A: snack of } 25 \mathrm{~g} \\
\text { pistachio nuts twice a day } \\
\text { for } 12 \text { weeks } \\
\text { Group B: control meal } \\
\text { without nuts } \\
\text { 8-week washout } \\
\text { The groups were } \\
\text { switched, and group B } \\
\text { received the same amount } \\
\text { of pistachios for } 12 \\
\text { weeks. }\end{array}$ & $\begin{array}{l}\text { Controlled blood glucose, blood } \\
\text { pressure, obesity, and inflammatory } \\
\text { markers in patients with diabetes }\end{array}$ \\
\hline $\begin{array}{c}\text { Gulati et al. (28), } \\
2014\end{array}$ & $\begin{array}{l}\text { The effect of pistachio on } \\
\text { body composition, } \\
\text { metabolic, inflammatory, } \\
\text { and oxidative stress }\end{array}$ & $\begin{array}{l}\text { RCT, } 60 \text { subjects with } \\
\text { metabolic syndrome }\end{array}$ & $\begin{array}{c}\text { Group I: intervention } \\
\text { group } \\
\text { unsalted pistachios ( } 20 \% \\
\text { energy)/daily } \\
\text { Group II: control group } \\
24 \text { weeks }\end{array}$ & $\begin{array}{l}\text { Positive impact on cardio-metabolic } \\
\text { profile in patients with metabolic } \\
\text { syndrome (reduction in WC, FBG, } \\
\text { total cholesterol, LDL, hs-CRP, TNF- } \\
\text { a FFAs, TBARS, and adiponectin } \\
\text { levels }\end{array}$ \\
\hline $\begin{array}{l}\text { Wang et al. (29), } \\
\qquad 2012\end{array}$ & $\begin{array}{l}\text { Impact of different dosages } \\
\text { of pistachios on body } \\
\text { weight, blood pressure, } \\
\text { blood lipids, blood glucose, } \\
\text { and insulin }\end{array}$ & $\begin{array}{l}\text { RCT, } 90 \text { subjects with } \\
\text { metabolic syndrome }\end{array}$ & $\begin{array}{c}\text { Three groups: } \\
\text { Group I: serving of } 42 \mathrm{~g} \\
\text { pistachios (RSG) } \\
\text { Group II: serving of } 70 \mathrm{~g} \\
\text { pistachios (HSG) } \\
\text { Group III: no pistachios } \\
\text { (DCG) } \\
\text { for } 12 \text { weeks }\end{array}$ & $\begin{array}{l}\text { No significant changes in body or } \\
\text { waist-to-hip ratio Improvements in } \\
\text { risk factors for metabolic syndrome }\end{array}$ \\
\hline Li et al. (30), 2010 & $\begin{array}{l}\text { The effects of pistachio } \\
\text { snack consumption on body } \\
\text { weight and lipid levels }\end{array}$ & $\begin{array}{l}59 \text { randomly selected } \\
\text { obese participants under } \\
\text { real-world conditions }\end{array}$ & $\begin{array}{c}\text { Group I: }(\mathrm{n}=31) 53 \mathrm{~g} \text { of } \\
\text { salted pistachios }=240 \\
\quad \text { cal } \\
\text { Group II: }(\mathrm{n}=28) 56 \mathrm{~g} \text { of } \\
\text { salted pretzels }=220 \mathrm{cal} \\
\text { For } 12 \text { weeks }\end{array}$ & $\begin{array}{l}\text { Pistachio is considered as a healthy } \\
\text { snack for individuals who are calorie } \\
\text { deficient and have low weight. } \\
\text { Has no effect on obesity. } \\
\text { Reduced triglycerides. }\end{array}$ \\
\hline $\begin{array}{l}\text { Mohammadi-Fard et } \\
\text { al. (31), } 2015\end{array}$ & $\begin{array}{c}\text { The effect of nut } \\
\text { consumption on blood } \\
\text { pressure }\end{array}$ & $21 \mathrm{RCT}$ articles & - & $\begin{array}{l}\text { Reduction in systolic blood pressure } \\
\text { and diastolic blood pressure }\end{array}$ \\
\hline
\end{tabular}

CHOs: Carbohydrates; RCT: Randomized controlled trial; RCCT: Randomized cross-over clinical trial; TG: Triglycerides; WB: White bread; B: Butter; Ch: Cheese; P: Pistachios; BP: Blood pressure; RCCF: Randomized cross-over controlled-feeding study; TF: Total fat; CVD: Cardiovascular disease; CVRF: Cardiovascular risk factors; MetS: Metabolic syndrome; CD: Control diet; PD: Pistachio-supplemented diet; WC: Waist circumference; FBS: Fasting blood sugar; hs-CRP: high-sensitivity C-reactive protein; FFAs: Free fatty acids; (TNF)- $\alpha$ : Tumor necrosis factor; TBARS: Thiobarbituric acid reactive substances; RSG: Recommended serving of pistachio; HSG: Higher serving of pistachio 
The effect of pistachio on individuals with prediabetes and diabetes, blood glucose, body weight, and blood pressure:

Pistachio changes the lipoprotein subclasses in individuals with pre-diabetes and makes them healthy. In a clinical trial, 54 individuals received either the supplementary pistachio diet (50\% carbohydrate and $33 \%$ fat, including 57 grams per day of pistachio) or the control diet (55\% carbohydrate and $30 \%$ fat) for 4 months (25). They reported that frequent consumption of pistachios could independently change the plasma lipoprotein levels, the density of the subsets of LDL, and LDL particle size, which can help reduce the risk of CVD and decrease mortality (25).

Hernandez et al. in a study stated that frequent consumption of pistachio as a nutritional strategy was useful for individuals with prediabetic. Pistachio lowers insulin and blood sugar, promotes healthy metabolism, and delays the adverse effects of metabolism in individuals with pre-diabetes (26). Another study was conducted on 48 patients with diabetes (27). Patients were divided into two groups of A and B. Group A received snacks that contained 25 grams of pistachios two times per day for 12 weeks. Group B were given food without seeds. After 12 weeks, the groups were switched, and group B received the same amount of pistachios for 12 weeks. The results showed that daily consumption of pistachio as a snack had beneficial effects on glycemic control, blood pressure, and obesity due to diabetes (27). Moreover, pistachio consumption, compared to white bread, lowered postprandial blood sugar and increased levels of glucagon-like peptide. Pistachio has small amounts of insulin properties. These effects could be useful for individuals with diabetes and metabolic syndrome (11).

In a clinical study, it was reported that adding pistachios to foods with a high glycemic index, such as steamed rice, pasta, and mashed potatoes, decreased the overall postprandial blood glucose response by 20 to $30 \%$ (8). Pistachio intervention with food had beneficial effects on metabolism and cardiovascular profile among Asian Indians with metabolic syndrome (28). Vanks et al. conducted a study on the effect of pistachio on body weight in individuals with Chinese metabolic syndrome (29). They stated that despite concerns about the consumption of pistachio which may promote weight, 42 or 70 grams of pistachios daily for 12 weeks did not lead to weight gain or increased waist-hip ratio in these individuals. In addition, pistachio intake may improve risk factors associated with metabolic syndrome (29). Those who have caloric restriction for weight loss could use pistachios as a controlled protein intake snack without worrying about gaining weight. Furthermore, in contrast to refined carbohydrates, such as pretzels, pistachios can also have beneficial effects on triglycerides (30). A systematic review and meta-analysis was performed by Mohammadi-Fard et al. in databases of Medline, Scopus, ISI, and Google Scholar (1958-2013) on pistachios (31). They stated that pistachio, in individuals who have type II diabetes, has a stronger effect on reducing systolic blood pressure $(\mathrm{P}=0.002)$ and diastolic blood pressure $(\mathrm{P}=0.040)$ (31). Darhar conducted a study on the potential health benefits of pistachio (8). Darhar stated that pistachio, due to its high potassium content (285 $\mathrm{mg}$ per ounce), $8 \%$ of daily value, provides the major ions required within a cell which is necessary for normal cell function and blood pressure (8). Clinical and observational studies have suggested that increased potassium uptake can control blood pressure in healthy individuals and those with high blood pressure (Table 1) (8).

\section{Discussion}

The present study assessed researches on the effects of pistachio on health (cardiovascular system, blood pressure, blood sugar, blood 
lipids, body weight, CVDs, diabetes, and metabolic syndrome) published from 2005 to 15 of July 2015.

Previous studies have suggested that pistachio, because of its different characteristics and compounds including polyunsaturated fatty acids, fiber, protein, minerals, and antioxidants, can increase health (3). The role of health in disease prevention was observed in the early 1950s in the Seven Countries Study (32). In this study, the mortality rate was inversely related to the proportion of unsaturated fatty acids to saturated fatty acids in the diet (32). Sivori et al. stated that the presence of healthy nutrients, including minerals, vitamins, unsaturated fats, and proteins, in seeds including pistachio and lack of cholesterol leads to heart health (33).

Pistachio, by improving fat (LDL, HDL) and triglycerides content, blood glucose, arterial stiffness, endothelial function, and blood pressure, improves health $(8,12,16,30)$. In other words, pistachios can help the promotion of health in individuals by improving blood vessel health, blood sugar control, appetite management, and weight control (8). Scientifically, atherosclerosis is the hardening of the arteries and narrowing of the vessels, and loss of tonicity and elasticity. It is the reduction of the vessels due to deposition of fat and cholesterol in the artery walls (34). According to the results of the mentioned researches, by improving the amount of fat and cholesterol, pistachio improves atherosclerosis. On the other hand, endothelial recovery has been attributed to the reduction of cholesterol, and presence of 1arginine (the protein in pistachio is a plant protein and has the amino acid of arginine), vitamins, and fiber in pistachio (19). In general, fatty acids in tissues and body fluids are associated with edible fat; therefore, the inclusion of these fatty acids in the diet is very important (35).

It seems that pistachio by containing vitamins, minerals, unsaturated fatty acids, fiber, and antioxidants can lead to cardiovascular health, and blood pressure, sugar, and lipids control.

According to research findings, pistachio consumption is effective on individuals with pre-diabetes $(25,26)$. Pistachio changes lipoprotein subclasses in individuals with prediabetes, and thus, improves their health. It also reduces postprandial glucose and insulin and promotes a healthy metabolism in individuals with pre-diabetes $(25,26)$. Alanzu et al. stated that the regular consumption of pistachios, as a nutritional strategy, is useful for pre-diabetes. It lowers blood sugar and insulin, and reverses the harmful consequences of pre-diabetic metabolism (36). Research has shown that individuals with pre-diabetes are 20 times more likely, than healthy individuals, to be diagnosed with diabetes (37). Therefore, nutrients in pistachios can help individuals with pre-diabetes in reducing blood sugar and insulin.

Moreover, research showed that consumption of pistachios had a positive effect on patients with diabetes $(3,11,27)$. Diabetes is a disease characterized mainly by hyperglycemia, and carbohydrate, fat, and protein dysfunction. This disease is caused by defects in insulin secretion or insulin action, or both. Its treatment consists of diet control, medication, exercise, and insulin secretion stimulation (38). Studies have shown that a healthy diet combined with pistachios, due to its compounds, has positive effects on glycemic control, blood pressure, and obesity in patients with diabetes (27). The substitution of carbohydrates with unsaturated fatty acids is a recognized therapeutic strategy in the treatment of diabetes (39). Therefore, a diet that contains a certain amount of pistachio can improve diabetes.

Pistachio intake may improve risk factors associated with metabolic syndrome $(28,29)$. Metabolic syndrome is associated with obesity, dyslipidemia (high triglycerides, or low HDL), hypertension, and abdominal obesity, and it increases the risk of type II diabetes and CVD. 
Lifestyle, diet, lack of physical activities, and genetics are the factors involved in this syndrome (40). It seems that a diet containing pistachio promotes the metabolic profile and decreases the harmful outcomes of metabolic syndrome.

Pistachio consumption does not lead to weight gain and it is considered as a controller of obesity $(29,30)$. Obesity, as a chronic disease, causes diseases such as hypertension, diabetes mellitus, hyperlipidemia, CAD, and so forth (41). Since one of the chief global health issues is increased obesity, it requires attention (42). Thus, a healthy diet containing nuts, due to its protein and fiber, increases the feeling of fullness and prevents weight gain. They also contain high amounts of vitamins, minerals, antioxidants, and phytosterols that can delay or prevent CVD and type II diabetes (43). In addition, pistachios, in comparison with a mixture of nuts, including pistachios, walnuts, almonds, cashews, hazelnuts, macadamia nuts, peanuts, pecans, and soy nuts, have the strongest effect on systolic and diastolic blood pressure in individuals who do not have type II diabetes (8, 31). In other words, pistachios, due to their high potassium content, are beneficial in controlling high blood pressure in healthy individuals and individuals with high blood pressure (8). High blood pressure is the major cause of CVD in the world and there is a direct relationship between the two (44). Nutritious substances have an important role in the development of hypertension. In other words, a healthy diet has beneficial effects on reducing CVD (44). In general, following the consumption of pistachios in specific ounces, the risk of CHD and CVDs, in general, decreases $(17,21-24)$.

In the world and also in Iran, the most common cause of death is CVD, and mainly atherosclerosis of the coronary arteries. The American Heart Association (AHA) has predicted that the prevalence of these diseases will increase by 2020 and they will be recognized as the number one cause of mortality $(45,46)$. Thus, awareness of the prevention of these diseases alleviates the many problems of the society. Pistachio and its compounds reduce the prevalence of these diseases; therefore, it is necessary that researchers perform extensive research on pistachio and, by obtaining the desired results, transfer the necessary knowledge to the community.

Pistachio can be suggested as part of a healthy diet for the prevention of chronic noncommunicable diseases. With multiple studies and larger sample size, the effects of pistachios on individuals with pre-diabetes could be examined further. In case of obtaining positive results, the diet of individuals with pre-diabetes should be largely amended, the risk of diabetes prevented, and their health improved. Moreover, future researches should examine the amount of pistachio serving (ounce).

\section{Conclusion}

Pistachio with its proteins, minerals (potassium, calcium, magnesium, manganese, and etc.), vitamins, and antioxidants has a positive impact on the human body health, including cardiovascular system, blood lipids, and blood pressure. Furthermore, unsaturated fats, through effecting blood lipoproteins, reduce CVD and diabetes, and control weight and metabolic syndrome. They can also help patients with prediabetes through changing the harmful metabolism of pre-diabetes.

\section{Acknowledgements}

Our sincere appreciation goes to all those who participated in and helped to conduct this study.

Conflict of Interest: None declared

\section{References}

1. Poulose SM, Miller MG, Shukitt-Hale B. Role of walnuts in maintaining brain health 
with age. J Nutr 2014; 144(4 Suppl):561S$6 \mathrm{~S}$.

2. Jenkins DJ, Kendall CW, Josse AR, Salvatore $\mathrm{S}$, Brighenti F, Augustin LS, et al. Almonds decrease postprandial glycemia, insulinemia, and oxidative damage in healthy individuals. J Nutr 2006; 136(12):2987-92.

3. Bulló M, Juanola-Falgarona M, HernándezAlonso P, Salas-Salvadó J. Nutrition attributes and health effects of pistachio nuts. Br J Nutr 2015; 113Suppl 2:S79-93.

4. Hyson DA, Schneeman BO, Davis PA. Almonds and almond oil have similar effects on plasma lipids and LDL oxidation in healthy men and women. J Nutr 2002;132(4):703-7.

5. Wu L, Piotrowski K, Rau T, Waldmann E, Broedl UC, Demmelmair H, et al. Walnutenriched diet reduces fasting non-HDLcholesterol and apolipoprotein B in healthy Caucasian subjects: A randomized controlled cross-over clinical trial. Metabolism 2014; 63(3):382-91.

6. Abdoshahi A, Mortazavi SA, Shabani AA, Elhamirad AH, Taheri M. Evaluation of protein, fat and fatty acids content of the pistachio (pistacia vera 1.) cultivars of Damghan, Iran. International Journal of Nuts and Related Sciences 2011; 2(4):15-24.

7. Saeb M, Nazifi S, Mirzaei A. studies on the effects of turpentine oil on the serum concentration of lipids and lipoproteins of female rabbits. The Journal of Shahid Sadoughi University of Medical Sciences 2004; 12(3):42-50.

8. Dreher ML. Pistachio nuts: composition and potential health benefits. Nutr Rev 2012; 70(4):234-40.

9. Afshari H, Talaei A, Sadeghi Gh. The study of some of the commponents in the pistachia nut and the effect of pollen grains on quantitive and qualitative traits of them. Journal of Horticulture Science 2008; 22(2):13-24.

10. Khoshnoodirad B. Pistachios; useful and brief seed [Internet]. 2014 [updated 2014 Oct 20; cited 2015 Mar 1]. Available from: http://www.tebyan.net/newindex.aspx?pid=28 6769

11. Kendall CW, Josse AR, Esfahani A, Jenkins DJ. The impact of pistachio intake alone or in combination with high-carbohydrate foods on post-prandial glycemia. Eur J Clin Nutr 2011; 65(6):696-702.
12. Sari I, Baltaci Y, Bagci C, Davutoglu V, Erel $\mathrm{O}$, Celik $\mathrm{H}$, et al. Effect of pistachio diet on lipid parameters, endothelial function, inflammation, and oxidative status: a prospective study. Nutrition 2010; 26(4):399404.

13. Mezinani S, Elhamirad AH, Piravivanak Z, Naghavi MR. Assessment of thermal stability, antioxidant properties of phenolic compounds and profiles of fatty acids in the oil extracted from the nuts (pistachios, walnuts, almonds). Journal of Innovation in Food Sciences and Technology 2011; 3(2): 45-52.

14. Nozady SM. Health and disease. $1^{\text {st }}$ ed. Tehran: Arjomand; 2006. Chapter 2, The comprehensive public hygiene; P.45-57.

15. Shabanian Podeh M. The importance of nutrition in human health. Laboratory Message 2015; 13(74-75):36-40.

16. Kasliwal RR, Bansal M, Mehrotra R, Yeptho KP, Trehan N. Effect of pistachio nut consumption on endothelial function and arterial stiffness. Nutrition 2015; 31(5):67885.

17. Sheridan MJ, Cooper JN, Erario M, Cheifetz CE. Pistachio nut consumption and serum lipid levels. J Am Coll Nutr 2007; 26(2):1418.

18. Kocyigit A, Koylu AA, Keles H. Effects of pistachio nuts consumption on plasma lipid profile and oxidative status in healthy volunteers. Nutr Metab Cardiovasc Dis 2006; 16(3):202-9.

19. Sari I, Baltaci Y, Bagci C, Davutoglu V, Erel $\mathrm{O}$, Celik $\mathrm{H}$, et al. Effect of pistachio diet on lipid parameters, endothelial function, inflammation, and oxidative status: a prospective study. Nutrition 2010; 26(4):399404.

20. Kay CD, Gebauer SK, West SG, KrisEtherton PM. Sarah K. Gebauer, Sheila G. West, Penny M. Kris-Etherton. Pistachios increase serum antioxidants and lower serum oxidized-LDL in hypercholesterolemic adults. J Nutr 2010; 140(6):1093-8.

21. Gebauer SK, West SG, Kay CD, Alaupovic P, Bagshaw D, Kris-Etherton PM. Effects of pistachios on cardiovascular disease risk factors and potential mechanisms of action: a dose-response study. Am J Clin Nutr 2008; 88(3):651-9.

22. O'Neil CE, Fulgoni VL 3rd, Nicklas TA. Tree Nut consumption is associated with better 
adiposity measures and cardiovascular and metabolic syndrome health risk factors in U.S. Adults: NHANES 2005-2010. Nutr J 2015; 14:64. doi: 10.1186/s12937-015-0052$\mathrm{x}$.

23. Holligan SD, West SG, Gebauer SK, Kay CD, Kris-Etherton PM. A moderate-fat diet containing pistachios improves emerging markers of cardiometabolic syndrome in healthy adults with elevated LDL levels. Br J Nutr 2014;112(5):744-52.

24. Sauder KA, McCrea CE, Ulbrecht JS, KrisEtherton PM, West SG. Pistachio nut consumption modifies systemic hemodynamics, increases heart rate variability, and reduces ambulatory blood pressure in well-controlled type 2 diabetes: a randomized trial. J Am Heart Assoc 2014; 3(4). pii: e000873. doi: 10.1161/JAHA.114.000873.

25. Hernández-Alonso $\mathrm{P}$, Salas-Salvadó J, Baldrich-Mora M, Mallol R, Correig X, Bulló M. Effect of pistachio consumption on plasma lipoprotein subclasses in pre-diabetic subjects. Nutr Metab Cardiovasc Dis 2015; 25(4):396-402

26. Hernández-Alonso $\mathrm{P}$, Salas-Salvadó J, Baldrich-Mora M, Juanola-Falgarona $\mathrm{M}$, Bulló M. resistance, inflammation, and related metabolic risk markers: a randomized Beneficial effect of pistachio consumption on glucose metabolism, insulin clinical trial. Diabetes Care 2014; 37(11):3098-105.

27. Parham M, Heidari S, Khorramirad A, Hozoori M, Hosseinzadeh F, Bakhtyari L, et al. Effects of pistachio nut supplementation on blood glucose in patients with type 2 diabetes: a randomized crossover trial. Rev Diabet Stud 2014; 11(2):190-6.

28. Gulati S, Misra A, Pandey RM, Bhatt SP, Saluja S. Effects of pistachio nuts on body composition, metabolic, inflammatory and oxidative stress parameters in Asian Indians with metabolic syndrome: a 24-wk, randomized control trial. Nutrition 2014; 30(2):192-7.

29. Wang X1, Li Z, Liu Y, Lv X, Yang W. Effects of pistachios on body weight in Chinese subjects with metabolic syndrome. Nutr J 2012; 11:20. doi: 10.1186/1475-289111-20

30. Li Z, Song R, Nguyen C, Zerlin A, Karp H, Naowamondhol $K$, et al. Pistachio nuts reduce triglycerides and body weight by comparison to refined carbohydrate snack in obese subjects on a 12-week weight loss program. J Am CollNutr 2010; 29(3):198203.

31. Mohammadifard N, Salehi-Abarghouei A, Salas-Salvadó J, Guasch-Ferré M, Humphries K, Sarrafzadegan N. The effect of tree nut, peanut, and soy nut consumption on blood pressure: a systematic review and metaanalysis of randomized controlled clinical trials. Am J Clin Nutr 2015; 101(5):966-82.

32. Saneie P, Azadbakh L. Methods to evaluate adherence to mediterranean diet: a review on epidemiologic studies. Journal of Isfahan Medical School 2012; 30(177):123-42.

33. Sheorey SD, Sengupta R, Hinge MA. Heart healthy nuts. International Journal of Current Pharmaceutical Review and Research 2011; 2(3):145-60.

34. Abbas Nejad A Norouzi M, Talebi Z. Investigation of pulsatile blood flow interaction with a viscoelastic artery and its effect on atherosclerosis. Journal of Fluid Mechanics and Aerodynamics 2015; 3(4)116.

35. Bahrami Gh. Antioxidant, hypolipidemic and anti atherosclerosis activities of different Cucurbita pepo extracts in rabbit. Kermanshah: Kermanshah University of Medical Sciences; 2010. Available from: http://research.kums.ac.ir/webdocument/load. action?webdocument_code $=1000 \&$ masterCo $\mathrm{de}=3000783$

36. .Hernández-Alonso P, Salas-Salvadó J, Baldrich-Mora M, Juanola-Falgarona M, Bulló M. Beneficial effect of pistachio consumption on glucose metabolism, insulin resistance, inflammation, and related metabolic risk markers: a randomized clinical trial. Diabetes Care 2014; 37(11):3098-105.

37. Fazelian S, Saedi Someeh Olia A, Mirfatahi M, Hoseini M, Sadrzade Yegane H, Heshmati J, et al. Effect of 1-arginine supplementation on antioxidant enzyme activity, total antioxidant capacity and body composition in patients with pre-diabetes. Arak Medical University Journal 2013; 16(9):25-35.

38. Zarekar M, Saghebjoo M, Foadodini M, Hedayati M. Effect of aerobic training and pistacia athlantica extract on GLUT-4 protein expression and muscle glycogen in diabetic rats. Iranian Journal of Endocrinology and Metabolism 2014; 16(4):245-53. 
39. Jenkins DJA, Kendall CWC, Banach MS, Srichaikul K, Vidgen E, Mitchell S, et al. Nuts as a replacement for carbohydrates in the diabetic diet. Diabetes Care 2011; 34(8):1706-11.

40. Zarkesh M, Guity K, Hosseinzadeh N, Azizi F, Daneshpour MS. Familial clustering of metabolic syndrome and its risk factors in Tehran lipid and glucose study. Journal of Ardabil University of Medical Sciences 2015; 15(4):384-94.

41. Daryanoosh F, Aminilari Z. The effect of 12 weeks of resistance training on the Apelin, Omentin-1 levels and insulin resistance in the elderly overweight women with type 2 diabetes. The Scientific Journal of Zanjan University of Medical Sciences 2015; 23(98 and 3):29-40.

42. Tabatabaei Molazi O, Larigani B. A review of the prevalence of obesity and its management in Iran. Iranian Journal of Diabetes and Metabolism 2013; 12(5):35774.
43. Jackson CL, Hu FB. Long-term associations of nut consumption with body weight and obesity. Am J Clin Nutr 2014; 100(Suppl 1):408S-11S.44.Kamran A, Azadbakht L, Shafaee Y, Sharifirad G. The effect of nutritional education on vitamin $\mathrm{C}$ and dietary fiber intake among patients with rural hypertension. Journal of Isfahan Medical School 2015; 33(321):1-13.

44. 45.Zand-Parsa AF, Salari A, Soati F, Izadpanah $\mathrm{P}$, Naghdipour $\mathrm{M}$, Momeni $\mathrm{M}$. Outcomes of clinical interventions in cardiovascular patients referred to emam khomeini hospital in Tehran, Iran. Journal of Guilan University of Medical Sciences 2013; 22(85):80-7.

45. 46.Sadeghifar J, Taghinejad F, Taghinejad H, Khodadadi E, Mousavi SM. Effect of education on knowledge and attitude of hospitalized patients in $\mathrm{CCU}$ and post $\mathrm{CCU}$ about risk factors of cardio-vascular disease. Iranian Journal of Nursing Research 2013; 8(1):39-48. 